DOI 10.37882/2223-2982.2020.12.31

\title{
МЕСТО И РОЛЬ КРЕСТЬЯНСТВА В УСТАНОВЛЕНИИ СОВЕТСКОЙ ВЛАСТИ НА СТАВРОПОЛЬЕ НА РУБЕЖЕ 1917-1918 ГОДОВ
}

\section{THE VALUE AND ROLE OF PEASANTRY IN ESTABLISHING SOVIET POWER IN THE STAVROPOL REGION AT THE TURN OF 1917-1918}

\section{Sakhranov}

Summary: The article is devoted to the Stavropol peasantry in the context of the establishment of soviet power in 1917-1918. In the course of the research, the author examines the attitudes of the Stavropol peasant community towards the organization of power in the agrarian region, traces the dynamics of political preferences of the peasantry and the reasons for their changes. The peasantry, being the predominant class in Stavropol region during the period under review, was the main driver of pro-soviet political changes in Stavropol region and took its place in the established system of power and management.

Keywords: Russia, Stavropol region, revolution, bolsheviks, sovietization, soviet power, Civil war, peasantry.

\author{
Сахранов Виктор Романович \\ Аспирант, Южный федеральный университет \\ (2. Ростов-на-Дону) \\ vicsakhranov@ya.ru
}

Аннотация: Статья посвящена крестьянству Ставрополья в контексте установления советской власти в 1917-1918 годах. В ходе проведенного исследования рассмотрены настроения в крестьянской среде Ставрополья к вопросам организации власти в аграрном регионе, прослежена динамика политических предпочтений крестьянства и причины их изменений. Крестьянство, будучи преобладающим классом Ставрополья в рассматриваемый период, явилось основным драйвером просоветских политических изменений на Ставрополье и заняло свое место в установившейся системе власти и управления.

Ключевые слова: Россия, Ставрополье, революция, большевики, советизация, советская власть, Гражданская война, крестьянство.
И нтерес к советизации Ставрополья и роли крестьянства в этом процессе связаны с исключительно слабым начальным положением большевиков в регионе ввиду неразвитости промышленности (в сравнении с соседними регионами), аграрной направленности Ставрополья, традиционно спокойным социальнополитическим положением.

Важнейшим условием создания революционной ситуации в таком сугубо аграрном регионе как Ставрополье являлось вовлечение крестьянства в процесс антиправительственных выступлений. В 1905-1907 годах революционные волнения ограничивались только Ставрополем и отчасти Кавминводами - аграрии губернии не были ими затронуты.

К 1917 году ситуация на Ставрополье изменилась. На протяжении долгого времени сельское население рассматривалось правительством как наиболее стабильная и терпеливая группа населения. С помощью крестьян царская власть стремилась решать самые разнообразные задачи как экономического, так и политического характера. Во взаимоотношениях власти и крестьянства господствовал приоритет государственных интересов при недостаточном внимании к интересам сельского на- селения. Подобное положение вещей неизбежно должно было привести к обострению противоречий. К 1917 году не только пролетарии, но и крестьяне Ставрополья были охвачены предреволюционным волнением [20, с. 15]. Примечательнее тем, что крестьянство Ставрополья по меркам соседей в целом было благополучнее во всех отношениях: это мы можем видеть как по данным о крупном рогатом скоте на душу населения, так и о среднем земельном пае [1, с. 88].

Конечно, высокий уровень благосостояния местного населения и его социальный состав не способствовал быстрому распространению революционных настроений. Несмотря на то, что экономика Ставропольской губернии несла убытки, связанные с Первой мировой войной, в отличие от центральных районов фактор тягот военного времени не имел решающего значения. Более значительную роль играли действия местной и центральной власти в отношении жителей губернии.

Первый Совет рабочих и солдатских депутатов Ставрополья был создан в апреле 1917 года. К тому времени в губернии массово восстанавливались старые и создавались новые профсоюзы. Поскольку большую часть членов Совета составляли эсеры и меньшевики, было 
принято решение о доверии Временному правительству и войне до победного конца.

Лозунг о продолжении войны вызвал недовольство не только немногочисленных ставропольских большевиков, но и части крестьянства. Наименее состоятельные аграрии требовали прекращения войны, создания крестьянских комитетов и конфискации земель крупных земельных собственников. В отдельных селах начались самопроизвольные конфискации и перераспределения земли.

В середине мая 1917 года состоялся Ставропольский губернский съезд крестьянских депутатов, на котором рассматривались вопросы будущих выборов в Учредительное собрание, форма устройства власти в стране, а также продовольственный вопрос. В работе съезда принимало участие 328 человек из 140 волостей Ставрополья, председательствовал Малий Л.Г. В резолюции об Учредительном собрании съезд подробно изложил свое видение предстоящей кампании, а именно проведение выборов по одномандатной мажоритарной системе через округа с населением 175 тыс. человек. Примечательными особенностями решений съезда о выборах являются положение об образовании отдельных избирательных округов в границах городов в случае их населения свыше 175 тыс. человек (данная мера безусловно была направлена на защиту интересов крестьянского населения как в масштабах страны - такие крупные города как Санкт-Петербург (2115 тыс. человек), Москва (1762 тыс. человек) и Саратов (235 тыс. человек) [18] могли бы представить в таком случае только по одному делегату, несмотря на численность населения и ожидаемо более высокую явку, так и в масштабах Ставрополья - город Ставрополь (62 тыс. человек) не смог бы представить самостоятельного делегата и был бы включен в состав округа совместно с близлежащими территориями с населением вдвое его превышающим, что с учетом общего населения Ставрополья (1239 тыс. человек) и его структуры также было бы целесообразно в интересах крестьянства) [19, с. 3]. Отдельно необходимо отметить, что в резолюции нашлось место и пункту об избирательном праве для солдат, причем по месту их дислокации (в том числе на фронте).

Анализируя вышеуказанные и иные положения резолюции о выборах в Учредительное собрание (ограниченность полномочий Учредительного собрания вопросами выработки основных положений и последующей ликвидации, наделение этих положений правовым статусом сразу после принятия, курс на проведение избирательной кампании и приоритет наказов делегатам в качестве высшей цели их работы в Учредительном собрании) необходимо отметить, что уровень политической культуры для крестьянских депутатов того времени был достаточно высоким, делегаты ясно понимали свои цели, интересы и методы их защиты, имели собственную политическую субъектность.

Однако, рассматриваемый съезд интересен и другими резолюциями, например - о предпочтительной форме правления. Здесь депутаты постановили демократическую республику в качестве наиболее приемлемой для крестьянства формы и детализировали свои представления с помощью положений о возможной структуре органов власти - отсутствие верховного главы государства, законодательная Дума в качестве представительного органа, вырабатывающего основную государственную линию, исполнителем которой выступает выборный законодательной Думой Совет Министров, в котором председатель не обладал бы какими-то особенными полномочиями и был бы лишь «первым среди равных». Кроме того, согласно резолюции, за народом оставалось право законодательной инициативы и отмены уже принятых законов в случае поддержки определенного количества граждан.

Путем анализа представлений крестьянских депутатов об идеальной форме правления можно сделать вывод, что наиболее близкой к данным формулировкам является парламентская республика. На таких позициях стояло ставропольское крестьянство на середину 1917 года.

Также внимания заслуживает и продовольственная резолюция, в которой съезд, несмотря на нараставшие антивоенные настроения в крестьянской среде, информировал профильные министерства Временного правительства о его всяческой поддержке и готовности снабжать продовольствием северные территории и русскую армию, однако просил о решении технических и организационных проблем в ходе его транспортировки и хранения [8].

Примечательно обращение Губернского совета крестьянских депутатов от 18.05.1917, в котором содержится просьба о финансовой поддержке деятельности совета по изданию литературы, организации избирательной деятельности, изданию газеты [3]. Здесь можно говорить об определенном уровне политизации и общественной деятельности крестьянского сословия, начале избирательной кампании по выборам делегатов в Учредительное собрание.

Ситуация в регионе хоть и была стабильной, но к августу 1917 года народный комиссар Старлычанов докладывал министру иностранных дел Временного правительства о нарастании анархических настроений в губернии [11, с. 75]. При этом, ряд документов свидетельствовал об отсутствии порядка среди населения и в 
более ранний период [7]. Однако данное положение все же еще нельзя назвать повсеместным.

При этом уже в сентябре 1917 года недовольство среди крестьянского населения Ставрополья достигло опасных значений - прежде всего оно было вызвано протестом против продовольственной политики, в соответствии с которой существенные объемы провизии отправлялись на фронт. Недовольство вылилось в существенных невыполнениях плановых показателей поставок продовольствия с территории Ставрополья.

Новость об Октябрьской революции в Петрограде достигла Ставрополя 28.10.1917. В течение следующих двух месяцев местная организация большевиков, включавшая в себя всего 200 человек, не получала из центра никаких инструкций относительно дальнейших действий $[17$, с. 97]. Между тем в данный период были зафиксированы случаи захвата большевиками власти в некоторых уездах губернии.

Ставропольская городская дума также не предпринимала никаких действий, ожидая созыва Учредительного собрания. При этом, призывы к проведению выборов звучали на заседаниях думы начиная с весны 1917 года. Местная окружная комиссия по выборам в Учредительное собрание была создана еще 12.08.1917. Голосование проводилось по принципу списков, что позволяло партиям занимать выгодное положение на выборах [15, c. 118-119].

Накануне выборов в Учредительное Собрание Ставропольский комитет РСДРП (б) выпустил воззвание, в котором призывал население Ставрополья принять участие в выборах и поддержать делегатов от большевиков, в котором апеллировали к вопросам о необходимости прекращения Первой мировой войны, а также о решении земельного вопроса в пользу крестьянских и земельных комитетов.

По решению Временного правительства в состав Учредительного собрания должны были войти 6 человек от Ставропольской губернии. Выборы проходили 1214.11.1917 путем тайного голосования методом подачи бюллетеней. По результатам выборов 88\% голосов получил список от партии эсеров, большевики получили только 5\% голосов [12, с. 90]. Подобная ситуация объяснялась тем, что социальной опорой эсеров традиционно являлось крестьянство, составлявшее большинство населения губернии.

Преобладание в Ставропольской губернии аграрного населения предопределило результат выборов в Учредительное собрание и дальнейшую активизацию деятельности местных большевиков, которые понима- ли, что установить свою власть в аграрном регионе, где порядка 90 \% местных жителей занимались сельским хозяйством, не заручившись поддержкой крестьянства было практически невозможно.

Одновременно по всей территории Ставрополья распространялись воззвания правых эсеров, выступавших от имени совета крестьянских депутатов с призывом собрать новый губернский съезд. На съезде предполагалось окончательно решить вопрос о характере власти в губернии, для чего следовало провести очередные выборы [21, с. 47].

После выборов в Учредительное собрание в Ставрополье усилилась агитация, проводившаяся силами членов партии большевиков, требовавших установления в губернии советской власти. 06.12.1917 на общем собрании Ставропольского Совета рабочих и солдатских депутатов был создан Военно-революционный комитет, возглавленный солдатом, студентом Петроградского университета и членом партии большевиков Анисимовым А.Н., провозглашена власть Совета рабочих, солдатских и крестьянских депутатов, а также отдельным пунктом постановлено, что приоритетом для большевиков на Ставрополье становится скорейший съезд крестьянских депутатов в целях правильного и близкого учета интересов крестьянства в работе Совета [4].

Ставропольские большевики все больше внимания уделяли крестьянству - на село были разосланы агитаторы из числа рабочих и солдат, они начали принимать активное участие в работе сходов крестьян, в выборах делегатов на IV крестьянский съезд и в Народное собрание, распространяли информацию о решениях, принятых на II Всероссийском съезде Советов рабочих, крестьянских и солдатских депутатов, которые находили широкий отклик среди селян [10].

И данная работа не прошла зря - существенная часть делегатов на IV крестьянский съезд устраивали большевиков. Однако на этом большевики не остановились и продолжали проводить агитационно-пропагандистскую работу с делегатами крестьянского съезда, прибывающими в город Ставрополь для участия в его работе. Результат агитационной работы мы можем видеть в той форме, которую приняли наказы избранным делегатам на крестьянский съезд [5].

IV крестьянский съезд состоялся 30.12.1917 и был примечателен его просоветским характером. Так в самом начале работы съезда делегатами было одобрено участие членов Совета солдатских депутатов Ставропольского гарнизона, в том числе Анисимова Н.А. Более того, в состав президиума были избраны представители большевиков. Далее работа крестьянского съезда боль- 
ше становится похожа на работу Съезда советов принимается резолюция о верховенстве власти народа и его представителей в лице Советов рабочих, крестьянских и солдатских депутатов, направляется приветствие Всероссийскому исполнительному комитету о его полной поддержке, декларируется проведение повсеместных перевыборов в Советы, упраздняется институт земств с возложением всех функций и имущества на Советы [6].

Именно с этого момента можно говорить о превращении большевиков в наиболее влиятельную политическую силу в Ставрополье, даже несмотря на то, что Общегубернское народное собрание должно было открыться только на следующий день.

В работе открывшегося 31.12.1917 Общегубернского народного собрания приняло участие порядка 500 делегатов, большая часть из которых не была лояльна большевикам и решения об организации власти в Ставрополье были бы приняты не в их интересах. Работа съезда проходила в здании Первой мужской гимназии Ставрополя.

Однако, большевики, воспользовавшись своими достижениями на IV крестьянском съезде, обеспечили изменение баланса сил в свою пользу - по ходатайству крестьянского съезда его участники были приняты в работу Общегубернского народного собрания, что означало абсолютное преобладание в нем крестьян [12, с. 91].

Благодаря этому политическому ходу большевикам удалось обеспечить поддержку большинства делегатов Общегубернского народного собрания. Более того, после избрания органов управления собрания, в состав которых вошли преимущественно большевики, была инициирована проверка каждого делегата на предмет легитимности его полномочий, по итогам которой удалось лишить мандатов часть нелояльных большевикам делегатов, а также таким способом привлечь на свою сторону колебавшихся делегатов.

В результате большевикам удалось провести в жизнь резолюцию об установлении 01.01.1918 на территории Ставрополья власти Советов рабочих, крестьянских и солдатских депутатов. Соответствующие известия были направлены руководству страны. Также были избраны советские органы управления в состав Совета вошли 180 членов, из которых 130 были крестьянами, 20 рабочими и 30 - солдатами. Данное соотношение ярко демонстрирует всю значимость крестьянства в установлении советской власти на Ставрополье. Иные Советы губернского уровня были упразднены. Помимо указанного, на собрании был одобрен Декрет о земле, принятый на II Всероссийском съезде советов [9].

Также был сформирован Исполнительный комитет из
30 человек, в состав которого вошли 18 представителей городского Совета рабочих и солдатских депутатов и 12 представителей крестьянского Губернского съезда (президиум исполкома был возглавлен Мирошниковым Г.И., в качестве заместителя (товарища) председателя был назначен Мещеряков П.И. (выходец из крестьянского сословия), секретаря - Селивановский Г.Г. (выходец из крестьянского сословия) [2]), и 09.01.1918 Губернский СНК.

Председателем СНК был избран Пономарев А.А., в ведении которого находился комиссариат внутренних дел и по статусу являвшийся губернским народным комиссаром. Анисимов Н.А. возглавил комиссариат военных дел и стал заместителем председателя СНК.

Необходимо отметить, что из 9 комиссаров СНК Ставрополья 4 были выходцами из крестьянского сословия, а именно: Медведев Ф.Ф. (по делам земледелия и сельского хозяйства), Гладков Я.В. (по делам земельных реформ), Тесленко Я.М. (по делам юстиции) и Петров Н.П. (по делам путей сообщения).

Таким образом, можно заключить, что аграрным сектором ведали комиссары, на собственном опыте имевшие представление о сельском хозяйстве.

Таким образом, представители партии большевиков, еще в октябре находившиеся на почти маргинальных позициях, возглавили Народное собрание, а потом в большинстве и вновь сформированные органы власти Ставрополья. При этом аграрии Ставрополья продолжали оставаться наиболее мощной политической силой республики [14, с. 21].

Несмотря на то, что ряд исследователей оценивает события, произошедшие в Ставрополе, как насильственный захват власти большевиками [16], данное утверждение представляется весьма спорным. Преобладание большевиков в президиуме Общегубернского Народного собрания явилось следствием целого ряда причин, среди которых поддержка солдат имеет не самое большое значение. Основу успеха большевиков составила активная агитационная работа, позволившая им склонить на свою сторону традиционно поддерживавшее эсеров крестьянство. Данный фактор стал решающим в момент заседания Общегубернского Народного собрания, призванного решить вопрос о дальнейшей судьбе власти на Ставрополье. Следует учитывать, что за несколько месяцев до заседания Общегубернского народного собрания партия большевиков была малочисленной и не рассматривалась обществом как сила, способная возглавить губернию. Таким образом, в отличие от других территорий, именно крестьянство на Ставрополье сыграло значительную роль в процессе установления советской власти. 


\section{ЛИТЕРАТУРА}

1. Б Борисенко И. Советские республики на Северном Кавказе в 1918 году / под ред. Лихницкого Н.; Северо-Кавказ. крайистпарт. - Ростов н/Д: «Северный Кавказ», 1930.- 2 т. 271 с.

2. ГАСК. Ф.Р-39, 0п. 1, Д. 1, ЛЛ. 1-2.

3. ГАСК. Ф.Р-65, Оп. 1, Д. 3, Л. 12.

4. ГАСК. Ф.Р-65, 0п. 1, Д. 10, Л. 157.

5. ГАСК. Ф.Р-65, 0п. 1, Д. 22, Л. 16.

6. ГАСК. Ф.Р-65, 0п. 1, Д 22, Л. 34.

7. ГАСК. Ф.Р-973, ОП. 1, Д. 25, Л. 19.

8. ГАСК. Ф.Р-1658 0п. 1. Д. 6. Л. 6-7.

9. ГАСК. Ф.Р-2567, 0П. 1, Д. 1, Л. 1.

10. ГАСК. Ф.Р-2618, 0п. 1, Д. 1, Л. 24.

11. Головенченко Ф.М. 1917 год в Ставропольской губернии / Комис. по проведению Х-й годовщины Октябрьской революции при окрисполкоме и Истпартотдел Ставропольского окркома ВКП(б) - Ставрополь: Истпартотдел Окркомв ВКП(б) и Юбилейная Комиссия, 1927. - 104 с.

12. Зверева Л.А. 1917 год на Ставрополье // Известия СоИГСИ. 2018. № 27 (66). С. 86-92.

13. Зверева Л.А. Органы государственной власти на Ставрополье (декабрь 1917-1929 г.): монография / - Ставрополь: Изд-во СевКавГТУ, 2011. - 182 с.

14. Ляшенко Е.В. Начальный этап становления советской системы органов местного управления на Ставрополье (1917-1936 гг.) // Вестник Ставропольского государственного университета. - 2010. - № 71. - С. 20-27.

15. Невская Т.А., Зверева Л.А. Развитие демократических институтов на Северном Кавказе в XVIII - первой четверти XX в.: от традиционного самоуправления к советской правовой системе / - Ставрополь: Изд-во СКФУ, 2019. - 184 с.

16. Оборский Б.Ю. Ставропольские большевики в 1917 году: от попыток сотрудничества к захвату власти // Гуманитарные и юридические исследования. 2015. - C. 104-110.

17. Очерки истории Ставропольской организации КПСС / под ред. Д.В. Кочура и др. - Ставрополь: Кн. изд-во, 1970. - 632 с.

18. Рашин А.Г. Население России за 100 лет (1811-1913 гг.): Стат. очерки / Под ред. акад. С.Г. Струмилина. - Москва: Госстатиздат, 1956. - 352 с.

19. Статистический ежегодник / под ред. Шарого В.И., зав. стат. отд. Совета съездов. - Санкт-Петербург: 1914. 560 с.

20. Суханова Н.И. Гражданская война 1917 - 1920 гг. на Северном Кавказе: социально-политический аспект: Автореф. дис. канд. истор. наук. Ставрополь, 2004.

21. Суханова Н.И. Эскалация гражданской войны на Северном Кавказе (февраль 1917-лето 1918 гг.) // Вестник Ставропольского государственного университета. 2003. № 32. С. $43-50$.

(c) Сахранов Виктор Романович (vicsakhranov@ya.ru)

Журнал «Современная наука: актуальные проблемы теории и практики» 